Terakreditasi S4 - SK No. 36/E/KPT/2019

Penerbit: Program Studi Pendidikan Geografi, FISE, Universitas Hamzanwadi

\title{
PENGEMBANGAN MODEL DAN METODE PERHITUNGAN BONUS DEMOGRAFI
}

\author{
Lalu Muh. Kabul ${ }^{*}$, Julio Nedo Darenoh ${ }^{2}$, Armin Subhani ${ }^{3}$ \\ ${ }^{1}$ Program Studi Rekayasa Perangkat Lunak, Fakultas Teknologi Informasi dan Komunikasi, Universitas Teknologi Mataram, Mataram, Indonesia \\ ${ }^{2}$ Analis Kebijakan Ahli Muda pada Perwakilan BKKBN Provinsi Nusa Tenggara Barat, Mataram, Indonesia \\ ${ }^{3}$ Program Studi Pendidikan Geografi, Fakultas Ilmu Sosial dan Ekonomi, Universitas Hamzanwadi, Selong, Indonesia \\ *Email Koresponden: kabullpp@yahoo.com
}

Diterima: 27-10-2020, Revisi: 09-12-2020, Disetujui: 09-12-2020

(C)2020 Program Studi Pendidikan Geografi, FISE, Universitas Hamzanwadi

\begin{abstract}
Abstrak Penelitian sebelumnya mengenai perhitungan bonus demografi masih terfokus hanya pada satu model, yakni rasio ketergantungan yang mencakup dua metode, yaitu metode Cheung et al dan Adioetomo. Penelitian ini dilaksanakan di Kabupaten Lombok Timur dan terdiri dari dua model, yakni model rasio ketergantungan dan model ekonomi daur hidup. Model rasio ketergantungan mencakup empat metode yaitu metode Cheung et al., Adioetomo, Komine \& Kabe, dan Golini. Sedangkan model ekonomi daur hidup mencakup dua metode yaitu rasio dukungan dan rasio daur hidup kesejahteraan pensiun terhadap total pendapatan tenaga kerja. Tujuan penelitian ini adalah mengetahui pengembangan model dan metode perhitungan bonus demografi. Penelitian ini menggunakan metode deskriptif kuantitatif. Berdasarkan analisis data diperoleh hasil bahwa model yang dikembangkan dalam perhitungan bonus demografi hanya model rasio ketergantungan, sedangkan model ekonomi daur hidup belum dikembangkan. Merujuk pada keempat metode dalam model rasio ketergantungan, tiga metode yang telah dikembangkan yakni metode Cheung et al, Adioetomo, Komine \& Kabe, sedangkan metode Golini belum dikembangkan. Berdasarkan metode Cheung et al., Kabupaten Lombok Timur telah mengalami bonus demografi pada tahun 2035-2045, tetapi berdasarkan metode Adioetomo dalam periode 2020-2045 belum mengalami bonus demografi dan berdasarkan metode Komine dan Kabe akan mengalami bonus demografi dalam periode 2020-2045.
\end{abstract}

Kata kunci: bonus demografi, rasio ketergantungan, ekonomi daur hidup

\begin{abstract}
Previously research on bonus demographic measurement is still only focused on one model, namely dependency ratio which coverage two methods namely Cheung et al and Adioetomo. This research was carried out in East Lombok. Regency and consist of two models, namely dependency ratio model and economic lifetime model. Dependency ratio model which coverage four methods namely Cheung et al, Adioetomo, Komine \& Kabe, and Golini. Meanwhile economic lifetime model which coverage two methods namely support ratio and ratio of lifecycle pension wealth to total labour income. The aimed of this research is to determine model and method of bonus demographic measurement. This research used descriptive quantitative method. Based on the data analysis the results obtained that model that developed for measurement of demographic bonus is only dependency ratio model, meanwible economic lifetime model isn't developed yet. Refer to the fourth method of dependency ratio model, three methods have been developed namely Cheung et al, Adioetomo, Komine and Kabe, meanwhile Golini hasn't been developed yet. Based on Cheung et al method East Lombok. Timur Regency has been achieved demographic bonus between 2035 and 2045, but based on Adioetomo method between 2020 and 2045 has not been achieved demographic bonus yet and based on Komine and Kabe method will be achieved demographic bonus between 2020 and 2045.
\end{abstract}

Keywords: demographic bonus, dependency ratio, economic lifetime

\section{PENDAHULUAN}

Demografi mempelajari struktur dan proses penduduk di suatu wialyah. Struktur penduduk meliputi jumlah, persebaran, dan komposisi penduduk. Struktur penduduk senantiasa berubah yang disebabkan karena proses demografi yaitu adanya kelahiran (fertility), kematian (mortality) dan migrasi penduduk (Jalaludin \& Fahri, 2013). Bonus demografi dapat dijelaskan dengan transisi demografi dimana transisi demografi adalah proses perubahan kelahiran dan kematian yang berlangsung dari tingkatan tinggi ke tingkatan rendah dalam kurun waktu tertentu. Istilah transisi demografi yang 
diperkenalkan pertama kali pada tahun 1929 oleh Warren Thompson meliputi 3 tahapan (Makripuddin, 2019). Tahap pertama, angka kelahiran tinggi dan relatif stabil bersamaan dengan itu angka kematian juga tinggi sehingga pertumbuhan penduduk yang merupakan selisih keduanya rendah. Tahap kedua, pertumbuhan yang cepat karena angka kematian turun dengan relatif cepat, sedangkan angka kelahiran turun dengan lamban dan hal ini mengakibatkan ledakan penduduk. Tahap ketiga, ditandai dengan angka kematian yang rendah dan angka kelahiran yang juga rendah dan hal ini menyebabkan pertumbuhan penduduk yang juga rendah.

Tabel 1. Tahapan Transisi Demografi

\begin{tabular}{cccc}
\hline Tahap & Kelahiran & Kematian & Pertumbuhan penduduk \\
\hline 1 & Tinggi & Tinggi & Rendah \\
2 & Turun & Turun & Tinggi \\
3 & Rendah & Rendah & Rendah \\
\hline
\end{tabular}

Sumber : Makripuddin, (2019); Hirschman, (2011).

Menurut Lee (2003), transisi demografi tahap pertama dimulai di Eropa Barat sebelum tahun 1800. Tingkat kelahiran tergolong tinggi yakni 4 sampai 5 anak pada setiap wanita demikian pula dengan tingkat kematian juga tergolong tinggi yang ditunjukkan dengan rendahnya usia harapan hidup sejak lahir berkisar antara 25 dan 35 tahun. Pertumbuhan penduduk relatif rendah yakni rata-rata sebesar 0,3 persen per tahun sebelum tahun 1700, tetapi kemudian meningkat menjadi diatas 1 persen pada abad ke-19. Di luar Eropa barat data kelahiran dan kematian baru tersedia di negara-negara sedang berkembang sebelum Perang Dunia II. Di India pada akhir abad ke-19 usia harapan hidup hanya mencapai 20 tahun dan tingkat kelahiran anak pada setiap wanita mencapai 6 sampai 7. Disisi lain Kabul (2019) menyatakan bahwa Malthus dalam karyanya Essay of the Principles of Population yang diterbitkan pada tahun 1798 bahwa untuk mengendalikan kelahiran tinggi dapat dilakukan melalui dua cara, yaitu preventive checks seperti pengekangan hawa nafsu, penundaan usia kawin dan positive checks yakni proses kematian karena adanya berbagai jenis penyakit, bencana alam, kelaparan dan perang.

Transisi demografi tahap kedua di Eropa Barat dimulai sejak tahun 1800 dan di negara-negara sedang berkembang pada akhir abad ke-19 terutama setelah Perang Dunia II. Di kawasan Eropa Barat seperti di Inggris tingkat kematian mengalami penurunan yang ditunjukkan dengan naiknya usia harapan hidup sejak lahir dari 40 tahun pada tahun 1861 menjadi 68 tahun pada tahun 1961. Faktor penyebab turunnya tingkat kematian tersebut yakni penemuan obat-obatan pencegah penyakit, perbaikan sanitasi dan pelayanan kesehatan, perbaikan gizi. Di sisi lain, kelaparan berhasil diatasi dengan ditemukannya teknologi pertanian. Di negara-negara sedang berkembang tingkat kematian mulai turun pada akhir abad ke-19 seperti India dengan naiknya usia harapan hidup sejak lahir dari 24 tahun pada tahun 1920 menjadi 62 tahun pada tahun 2000. Setelah Perang Dunia II di China usia harapan hidup sejak lahir naik dari 41 tahun pada tahun 1950-1955 menjadi 70 tahun pada tahun 1995-1999 (Lee, 2003). Berkaitan dengan turunnya tingkat kematian, pilihan keluarga dalam memiliki anak sebagaimana dikemukakan Becker peraih nobel ekonomi tahun 1992 bukanlah pada kuantitas, melainkan kualitas. Pengembangan kualitas anak membutuhkan investasi dalam bidang pendidikan dan kesehatan yang semakin mahal. Sejalan dengan makin mahalnya biaya dalam bidang pendidikan dan kesehatan, kemudian keluarga memutuskan untuk membentuk keluarga kecil dengan memiliki sedikit anak dengan menggunakan alat kontrasepsi, sehingga tingkat kelahiran mengalami penurunan. Pada tahun 2003 di seluruh belahan dunia lebih dari separuh pasangan usia subur menggunakan alat kontrasepsi dibandingkan tahun 1960 hanya 10 pasangan usia subur yang menggunakan alat kontrasepsi (Lee, 2003; Bloom et al., 2003).

Bayi yang lahir pada transisi demografi tahap kedua itu kemudian tumbuh menjadi penduduk usia produktif beberapa tahun kemudian dimana proporsi jumlah penduduk usia produktif lebih banyak dibandingkan penduduk tidak produktif yakni anak-anak dan orang tua atau lanjut usia (lansia). Dalam pada itu, situasi inilah yang disebut sebagai bonus demografi atau demographic dividend (Lee, 2003; Bloom et al., 2003; Mason et al., 2017). Berlimpahnya penduduk usia produktif, maka terjadi suplai tenaga kerja dalam jumlah besar yang dapat meningkatkan pendapatan per per kapita. Disisi lain, dengan turunnya tingkat kelahiran, maka keluarga memiliki sedikit anak yang memungkinkan perempuan memasuki pasar tenaga kerja sehingga dapat berkontribusi pada pendapatan keluarga (Bloom et al., 2003). Dengan 
naiknya usia harapan hidup sejak lahir, maka terjadi perpanjangan usia pensiun dan ketika tenaga kerja memasuki usia 40 hingga 60 tahun, mereka telah mempersiapkan tabungan dalam bentuk modal maupun asset yang akan dimanfaatkan ketika pensiun. Akumulasi modal dan asset tersebut berkontribusi bagi pertumbuhan ekonomi. Pada transisi demografi tahap kedua tersebur, penduduk usia kerja memiliki tingkat pendidikan dan kesehatan yang lebih baik. Tingkat pendidikan berkorelasi dengan tingkat pendapatan. Tenaga kerja dengan lama sekolah 6 tahun memiliki pendapatan 50 persen lebih tinggi dibandingkan tenaga kerja yang tidak pernah sekolah, peningkatannnya mencapai 120 persen jika lama sekolah 12 tahun dan 200 persen jika lama sekolah 17 tahun. Dalam pada itu, keajaiban ekonomi (economic miracle) yang dialami Asia merupakan kontribusi dari bonus demografi (Bloom et al, 2003 ; Lee, 2003).

Pada transisi demografi tahap kedua tidak hanya tingkat kematian yang mengalami penurunan, tetapi juga tingkat kelahiran. Di negara-negara sedang berkembang tingkat kelahiran pada setiap wanita pada tahun 1950-an mencapai 6 anak kemudian diproyeksikan turun menjadi kurang dari 3 anak pada tahun 2050 (Lee, 2003). Di Indonesia tingkat kelahiran pada tahun 1950-an yakni 5,6 anak per wanita kemudian turun menjadi 2,3 anak per wanita pada tahun 1990-an. Pertumbuhan penduduk rata-tata pada transisi demografi tahap kedua relatif tinggi yakni sebesar 2 persen. Indonesia sebagai salah satu negara sedang berkembang memiliki pertumbuhan penduduk sebesar 2,36 persen pada tahun 19651970 kemudian turun menjadi 1,39 persen pada tahun 1995-2000 (Oey-Gardiner \& Gardiner, 2013). Sedangkan transisi demografi tahap ketiga diproyeksikan terjadi setelah tahun 2050 dengan tingkat kelahiran dan tingkat kematian rendah dan pertumbuhan penduduk nol (zero growth) diproyeksikan pada tahun 2100. Sedangkan negara-negara maju telah lebih dahulu mencapai transisi demografi tahap kedua maupun ketiga. Pada tahun 1950-an pertumbuhan penduduk di negara-negara maju mencapai 1 persen kemudian turun menjadi 0,69 persen pada tahun 1965-1990 dan telah mencapai zero growth pada tahun 2000-2050 (Lee, 2003; Hirschman, 2011).

Berdasarkan uraian sebelumnya bahwa bonus demografi terjadi pada transisi demografi tahap kedua. Perhitungan bonus demografi diperlukan untuk mengetahui apakah suatu negara atau daerah telah mengalami bonus demografi atau belum. Di era otonomi daerah sekarang ini, pengendalian penduduk dan keluarga berencana menjadi kewenangan wajib daerah sebagaimana diamanatkan dalam UU Nomor 23 Tahun 2014 tentang Pemerintahan Daerah. Kebijakan daerah mengenai pengendalian penduduk dan keluarga berencana tersebut kemudian dituangkan dalam Grand Design Pembangunan Kependudukan (GDPK) sebagaimana diamanatkan dalam Peraturan Presiden Nomor 153 Tahun 2014 tentang GDPK. Lebih jauh, kebijakan daerah yang dituangkan dalam GDPK tersebut diformulasikan berdasarkan perhitungan bonus demografi. Dalam perhitungan bonus demografi dikenal 2 model yaitu rasio ketergantungan (dependency ratio) dan ekonomi daur hidup (economic lifetime)(Kabul \& Haliliah, 2019). Selanjutnya, Kabul \& Haliliah (2019) menyatakan bahwa model rasio ketergantungan meliputi 4 metode, yaitu metode Cheung et al., (2004); metode Adioetomo (2012); metode Komine \& Kabe (2009); dan metode Golini (2014). Sedangkan model ekonomi daur hidup meliputi 2 metode yakni rasio dukungan (support ratio) dan metode rasio daur hidup kesejahteraan pensiun terhadap total pendapatan tenaga kerja (Mason et al., 2017).

Dari berbagai penelitian mengenai perhitungan bonus demografi yang telah dilakukan sebelumnya hanya terfokus pada model rasio ketergantungan, terutama pada 2 metode yaitu metode Cheung et al (Makripuddin, 2019) dan metode Adioetomo (BPS, 2012). Perhitungan bonus demografi dalam penelitian ini berbeda dengan penelitian sebelumnya dimana penelitian ini tidak hanya terfokus pada model rasio ketergantungan, tetapi juga mencakup model ekonomi daur hidup. Di sisi lain, dalam penelitian ini metode perhitungan bonus demografi pada model rasio ketergantungan tidak hanya mencakup 2 metode seperti penelitian sebelumnya, tetapi meliputi semua metode atau sebanyak 4 metode. Pada model ekonomi daur hidup juga mencakup semua metode atau sebanyak 2 metode. Tujuan penelitian adalah mengetahui pengembangan model dan metode perhitungan bonus demografi.

\section{METODE PENELITIAN}

Dalam penelitian ini digunakan metode deskriptif kuantitatif yakni mendeskripsikan fenomena seperti adanya secara alami dan tidak membahas bagaimana dan mengapa terjadinya fenomena tersebut 
(Neuman, 2014; Aliman et al., 2020). Pada tahap awal dilakukan studi pustaka (library research) kemudian ditindaklanjuti dengan survey meliputi pengumpulan data dan analisis data. Data yang dikumpulkan meliputi data primer dan data sekunder.

Data primer dikumpulkan melalui wawancara dan diskusi kelompok terarah (focus group discussion) dengan semua institusi di Lombok Timur yang terlibat dalam penyusunan Grand Design Pembangunan Kependudukan (GDPK) Lombok Timur 2020-2045. Institusi dimaksud adalah Dinas P3A dan KB, Dinas Tenaga Kerja dan Transmigrasi, Dinas Koperasi dan UMKM, Dinas Peternakan dan Kesehatan Hewan, Dinas Pekerjaan Umum dan Perumahan Rakyat, Dinas Permukiman dan Kawasan Permukiman, Dinas Kependudukan dan Catatan Sipil, Dinas Komunikasi Informasi dan Persandian, Dinas Ketahanan Pangan, Bappeda, Dinas Pertanian, Dinas Pendidikan dan Kebudayaan, BPS Lombok Timur, Koalisi Kependudukan Lombok Timur, Lembaga Perlindungan Anak Lombok Timur, Dinas Kelautan dan Perikanan. Sedangkan data sekunder diperoleh dari BPS Lombok Timur dan institusi terkait lainnya. Data yang terkumpul dianalisis menggunakan statistik deskriptif kemudian ditampilkan dalam bentuk tabel dan grafik.

\section{TEMUAN DAN PEMBAHASAN \\ Rasio Ketergantungan}

Dokumen perencanaan untuk lima tahun kedepan yang telah dimiliki Lombok Timur adalah Rencana Pembangunan Jangka Menengah Daerah (RPJMD) Lombok Timur 2018-2023 yang memuat visi, misi dan strategi serta program pembangunan untuk mencapai visi dan misi. Dalam pada itu, RPJMD Lombok Timur 2018-2023 merupakan penjabaran tahap keempat dari Rencana Pembangunan Jangka Panjang Daerah (RPJPD) Lombok Timur 2005-2025. Setiap institusi baik dinas maupun badan daerah menjabarkan RPJMD Lombok Timur 2018-2023 kedalam Rencana Strategis (Renstra) 20182023 dan selanjutnya Renstra 208-2023 tersebut dijabarkan setiap tahun oleh dinas dan badan daerah kedalam rencana kerja. Program strategis yang disusun oleh setiap dinas dan badan daerah dalam Renstra 2018-2023 hendaknya memperhatikan aspek kependudukan atau lebih dikenal dengan program pembangunan berbasis kependudukan. Dalam konteks pembangunan berbasis kependudukan tersebut, maka perhitungan bonus demografi menjadi sebuah keniscayaan. Perhitungan bonus demografi hanya terdapat dalam GDPK Lombok Timur 2020-2045, tetapi tidak ditemukan dalam RPJMD Lombok Timur 2018-2023 maupun RPJPD Lombok Timur 2005-2025. Kedepan selain dalam GDPK Lombok Timur 2020-2045 perhitungan bonus demografi hendaknya dituangkan dalam RPJMD Lombok Timur 2023-2028 dan RPJPD 2025-2045. Kaitan antara bonus demografi dengan GDPK, RPJMD dan RPJPD ditampilkan pada gambar 1.

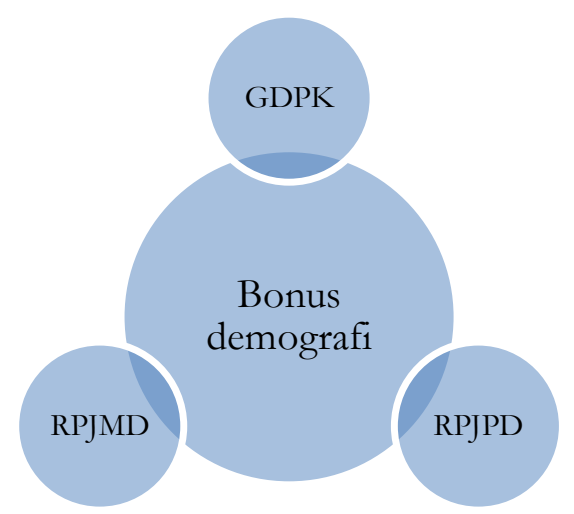

Gambar 1. Kaitan Bonus Demografi dengan GDPK, RPJMD dan RPJPD (Sumber: Peneliti, 2020)

Dalam model rasio ketergantungan (dependency ratio) dimana bonus demografi dihitung berdasarkan rasio antara jumlah penduduk usia tidak produktif dengan jumah penduduk usia produktif. Jumlah penduduk usia tidak produktif yang dimaksud adalah penduduk muda (0-14 tahun) dan penduduk tua atau lanjut usia ( $\geq 65$ tahun), sementara penduduk usia produktif adalah penduduk yang berusia 15 sampai 64 tahun. Rasio ketergantungan di Lombok Timur sebagaimana ditampilkan pada 
gambar 2 mengalami penurunan dari 53,88 pada tahun 2020 menjadi 50,11 pada tahun 2030 dan mencapai dibawah 50 pada tahun 2035-2045 yakni masing-masing sebesar 49,51 pada tahun 2035 kemudian sebesar 49,62 pada tahun 2040 dan 49,74 pada tahun 2045. Rasio ketergantungan muda (dependency ratio muda) yang merupakan rasio antara jumlah penduduk muda (0-14) dengan jumlah penduduk usia produktif juga mengalami penurunan dari 45,35 pada tahun 2020 menjadi 42,01 pada tahun 2025 dan 38,73 pada tahun 2030 dan terus turun hingga mencapai 35,91 pada tahun 2045. Sebaliknya, rasio ketergantungan lanjut usia atau tua (dependency ratio tua) justru mengalami kenaikan dari 8,53 pada tahun 2020 menjadi 9,83 pada tahun 2025 dan 11,38 pada tahun 2030 dan terus mengalami kenaikan hingga mencapai 13,82 pada tahun 2045. Dalam pada itu,. suatu daerah atau wilayah dinyatakan mengalami penuaan penduduk (ageing population) jika rasio ketergantungan sebesar 30 persen atau kurang (Heryanah, 2015).

Di Lombok Timur sebagaimana ditampilkan pada gambar 2 bahwa rasio ketergantungan dalam periode tahun 2020-2045 berada diatas 30 persen artinya Lombok Timur belum mengalami penuaan penduduk dalam periode 2030-2045. Model rasio ketergantungan meliputi 4 metode perhitungan, yaitu metode Cheung et al., (2003), metode Adioetomo (2012), metode Komine \& Kabe (2009) dan metode Golini (2014).

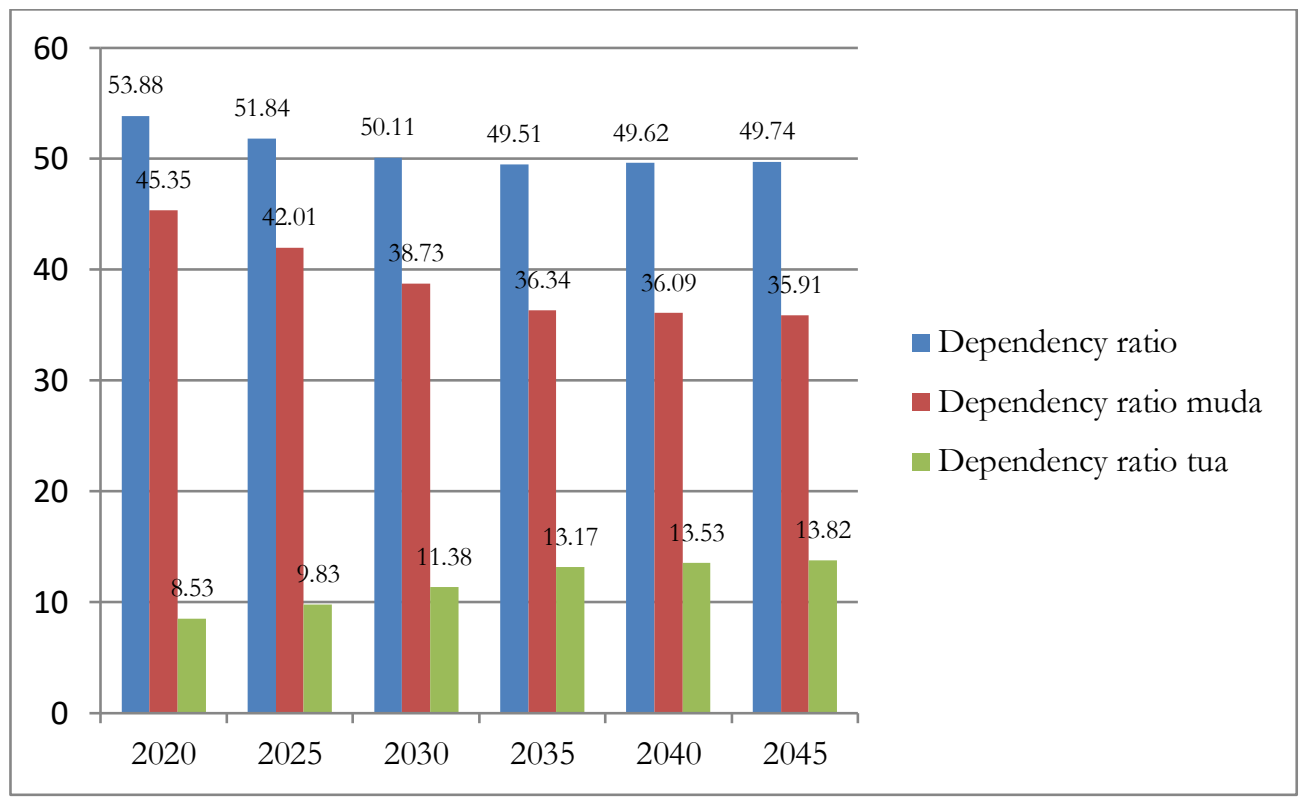

Gambar 2. Rasio Ketergantungan di Lombok Timur Tahun 2020-2045

(Sumber: BPS Lombok Timur, 2020)

Pertama, metode Cheung et al., (2003) menggunakan rasio ketergantungan (dependency ratio) sebagai pendekatan untuk menghitung bonus demografi dimana penduduk usia tidak produktif yang dimaksud adalah penduduk muda (0-14 tahun) dan penduduk tua atau lanjut usia ( $\geq 65$ tahun), sedangkan penduduk usia produktif adalah penduduk usia 15 sampai 64 tahun. Dalam metode Cheung et al., (2003) suatu negara atau daerah dinyatakan telah mengalami bonus demografi, ketika rasio ketergantungan (dependency ratio) berada dibawah 50. Rasio ketergantungan Lombok Timur dalam periode 2010-2020 sebagaimana ditampilkan pada gambar 2 berada dibawah 50 dalam periode tahun 2035-2045 artinya berdasarkan metode Cheung et al., (2003) Kabupaten Lombok Timur telah mengalami bonus demografi dalam periode tahun 2035-2045.

Kedua, metode Adioetomo (2012) juga menggunakan rasio ketergantungan (dependency ratio) sebagai pendekatan untuk menghitung bonus demografi dimana penduduk usia tidak produktif yang dimaksud Adioetomo adalah penduduk muda (0-14 tahun) dan penduduk tua atau lanjut usia ( $\geq 65$ tahun), sedangkan penduduk usia produktif adalah penduduk usia 15 sampai 64 tahun. Dalam metode Adioetomo (2012) suatu negara atau daerah dinyatakan telah mengalami bonus demografi, ketika rasio ketergantungan (dependency ratio) mencapai 44. Rasio ketergantungan di Kabupaten Lombok Timur 
dalam periode 2020-2045 sebagaimana ditampilkan pada gambar 2 masih diatas 44 sehingga berdasarkan metode Adioetomo (2012) Kabupaten Lombok Timur belum mengalami bonus demografi.

Ketiga, metode Komine \& Kabe (2009) menggunakan pendekatan rasio ketergantungan (dependency ratio) untuk menghitung bonus demografi. Dalam metode Komine dan Kabe penduduk usia tidak produktif yang dimaksud adalah penduduk muda (0-14 tahun) dan penduduk tua atau lanjut usia ( $\geq 65$ tahun), sementara penduduk usia produktif adalah penduduk yang berusia 15 sampai 64 tahun. Dalam metode Komine \& Kabe (2009) bahwa suatu negara atau daerah telah mengalami bonus demografi, ketika rasio ketergantungan (dependency ratio) mulai mengalami penurunan secara terus menerus. Rasio ketergantungan di Kabupaten Lombok Timur dalam periode 2020-2045 sebagaimana ditampilkan pada gambar 2 mengalami penurunan secara terus menerus. Dengan perkataan lain Kabupaten Lombok Timur dalam periode 2020-2045 telah mengalami bonus demografi berdasarkan metode Komine \& Kabe (2009).

Keempat, metode Golini (2014) juga menggunakan rasio ketergantungan (dependency ratio) sebagai pendekatan untuk menghitung bonus demografi, tetapi penduduk usia tidak produktif yang dimaksud Golini adalah penduduk muda (0-14 tahun) dan penduduk tua atau lanjut usia ( $\geq 60$ tahun), sedangkan penduduk usia produktif adalah penduduk usia 15 sampai 59 tahun. Dalam metode Golini bahwa suatu negara atau daerah dinyatakan telah mengalami bonus demografi, jika rasio ketergantungan (dependency ratio) berada dibawah 66. Perhitungan bonus demografi berdasarkan metode Golini di Kabupaten Lombok Timur belum bisa dikembangkan karena BPS Lombok Timur belum melakukan perhitungan rasio ketergantungan (dependency ratio) berdasarkan definisi rasio ketergantungan yang dikemukakan oleh Golini.

\section{Ekonomi Daur Hidup}

Ekonomi daur hidup (economic lifetime) dikembangkan oleh Mason et al., (2017) dan telah diadopsi oleh Perserikatan Bangsa-Bangsa (PBB) sebagai model perhitungan bonus demografi global. Meskipun telah diadopsi oleh PBB sebagai model global, tetapi model ekonomi daur hidup ini belum dikembangkan di Indonesia termasuk di Kabupaten Lombok Timur. Dalam model ekonomi daur hidup tersebut dikenal 2 jenis bonus demografi, yakni bonus demografi pertama (first demographic dividend) dan bonus demografi kedua (second demographic dividend). Dari sisi ekonomi daur hidup penduduk terdiri dari 3 tahap, yaitu penduduk muda, dewasa dan tua atau lanjut usia (lansia). Penduduk muda dan lansia umumnya lebih banyak mengkonsumsi daripada menghasilkan dalam aktivitasnya sebagai tenaga kerja, sehingga penduduk muda dan lansia dikenal dengan konsumen efektif. Sedangkan penduduk dewasa sebagai tenaga kerja lebih banyak menghasilkan daripada mengkonsumsi. Penduduk dewasa yang merupakan penduduk usia kerja dikenal dengan pekerja efektif atau produsen (Mason et al., 2017; United Nations, 2013).

Bonus demografi pertama dihitung berdasarkan rasio dukungan (support ratio), SR ( $\mathrm{t}$ ) yang merupakan rasio jumlah pekerja efektif atau produsen pada tahun $t, L(t)$ dengan jumlah konsumen efektif pada tahun t, N(t) dengan rumus sebagai berikut (Mason et al., 2017):

$$
\operatorname{SR}(\mathrm{t})=\frac{\mathrm{L}(\mathrm{t})}{\mathrm{N}(\mathrm{t})}
$$

Jumlah pekerja efektif atau produsen pada tahun $t, L(t)$ dihitung dengan menggunakan rumus sebagai berikut (Mason et al., 2017):

$$
\begin{gathered}
\mathrm{L}(t)=\sum \mathrm{Y}(x) \mathrm{P}(x, t) \\
\mathrm{Y}(x)=\mathrm{Y}(x, b) / \mathrm{Y}(30-49, b)
\end{gathered}
$$

Dimana $\mathrm{Y}(\mathrm{x})$ adalah indeks pendapatan tenaga kerja yaitu pendapatan perkapita tenaga kerja pada usia $\mathrm{x}$ dibagi rata-rata pendapatan per kapita tenaga kerja usia 30-49 tahun pada tahun dasar $\mathrm{b}$ dan $\mathrm{P}(\mathrm{x}, \mathrm{t})$ adalah penduduk usia $\mathrm{x}$ pada tahun t. Disisi lain, jumlah konsumen efektif pada tahun $\mathrm{t}, \mathrm{N}(\mathrm{t})$ dihitung dengan rumus sebagai berikut (Mason et al., 2017):

$$
\begin{gathered}
\mathrm{N}(t)=\sum \mathrm{c}(x) \mathrm{P}(x, t) \\
\mathrm{c}(x)=\mathrm{c}(x, b) / \mathrm{c}(30-49, b)
\end{gathered}
$$


Dimana $\mathrm{c}(\mathrm{x})$ adalah indeks konsumsi yang mengukur konsumsi pada setiap umur penduduk dibandingkan dengan konsumsi penduduk usia 30-49 tahun. Dalam pada itu, hubungan support ratio, SR (t) dengan model ekonomi dapat dinyatakan dalam persamaan berikut (Mason et al., 2017):

$$
\frac{Y(t)}{N(t)}=\frac{Y(t)}{L(t)} \times \operatorname{SR}(t)
$$

Dimana $Y(t) / N(t)$ adalah pendapatan per konsumen efektif, $Y(t) / L(t)$ adalah pendapatan per pekerja efektif dan $\mathrm{Y}(\mathrm{t}) / \mathrm{L}(\mathrm{t})$ berkaitan dengan bonus demografi kedua. Dalam pada itu, bonus demografi pertama dimulai dari support ratio dengan nilai terendah hingga tertinggi. Perhitungan support ratio sebagai bonus demografi pertama di Kabupaten Lombok Timur belum bisa dikembangkan karena data indeks pendapatan tenaga kerja dan indeks konsumsi yang diperlukan untuk perhitungan support ratio tersebut belum tersedia di BPS Kabupaten Lombok Timur.

Di sisi lain, bonus demografi kedua berkaitan dengan penuaan penduduk (ageing population). Untuk mengantisipasi kebutuhan konsumsi ketika tua saat menikmati pensiun, pekerja ketika menginjak usia 45 tahun sudah mulai mempersiapkan hari tuanya dengan cara menyisihkan bagian dari pendapatannya untuk dijadikan asset ataupun modal dimana akumulasi asset dan modal inilah yang akan dimanfaatkan untuk memenuhi konsumsi ketika pensiun. Selain itu, kebutuhan pensiun juga dapat dipenuhi dari transfer naik transfer dari sektor publik (misalnya gaji pensiun), transfer dari sektor swasta maupun transfer dari keluarga. Akumulasi asset, modal dan transfer sejak seorang pekerja berusia 45 tahun hingga ia pensiun dikenal dengan daur hidup kesejahteraan pensiun atau W45 (t). Dengan demikian, bonus demografi kedua adalah rasio daur kesejahteraan pensiun terhadap total pendapatan tenaga kerja dan dinyatakan dalam persamaan berikut ini (Mason et al., 2017):

$$
\begin{gathered}
\frac{Y(t)}{L(t)}=\frac{W 45(t)}{Y l(t)} \\
\frac{W 45(t)}{Y l(t)}=\left[\frac{\mathrm{c}(30-49, b)}{y i(30-49, b)}\right]\left[\frac{\sum W N(z, t)}{L(t)}\right]-\left[\frac{\sum W I(z, t)}{L(t)}\right]
\end{gathered}
$$

Bonus demografi kedua dimulai ketika rasio daur kesejahteraan pensiun terhadap total pendapatan tenaga kerja [W45(t)/Yl(t)] berada pada nilai terendah hingga tertinggi. Dalam pada itu, perhitungan rasio daur kesejahteraan pensiun terhadap total pendapatan tenaga kerja di Kabupaten Lombok Timur belum bisa dikembangkan karena data daur kesejahteraan pensiun dan pendapatan tenaga kerja yang diperlukan untuk perhitungan belum tersedia di BPS Lombok Timur. Kesejahteraan pensiun (W45) meliputi dua komponen yaitu nilai asset (A45) dan dana transfer pensiun neto melalui sektor publik dan keluarga untik penduduk usia 45 tahun keatas (WT45) dan dinyatakan dalam persamaan berikut ini (Mason et al., 2017):

$$
\mathrm{W} 45=\mathrm{A} 45+\mathrm{WT} 5
$$

Diasumsikan bahwa asset dan dana transfer pensiun adalah konstan, sehingga persamaan pertumbuhan kesejahteraan pensiun atau gr [W45] yaitu sebagai berikut (Mason et al., 2017):

$$
\operatorname{gr}[\mathrm{W} 45]=\operatorname{gr}[\mathrm{A} 45]+\operatorname{gr}[\mathrm{WT} 45]
$$

Selain itu diasumsikan bahwa total asset penduduk usia 45 tahun keatas atau gr $[\mathrm{K}]$ memiliki tingkat pertumbuhan yang sama dengan tingkat pertumbuhan kesejahteraan pensiun atau gr[W45], sehingga diperoleh persamaan berikut ini (Mason et al., 2017):

$$
\operatorname{gr}[\mathrm{K}] \approx \operatorname{gr}[\mathrm{WT} 45]
$$

Akhirnya diperoleh hubungan antara pertumbuhan modal atau rasio modal terhadap pendapatan $(\operatorname{gr}[\mathrm{K} / \mathrm{Y}]$ dan pertumbuhan output per tenaga kerja efektif $(\mathrm{gr}[\mathrm{Y} / \mathrm{L}]$. Diasumsikan bahwa 
output ditentukan dua faktor, yaitu modal dan tenaga kerja efektif dan bentuk hubungannya berdasarkan fungsi produksi Cobb-Douglas adalah sebagai berikut (Mason et al., 2017):

$$
\operatorname{gr}[\mathrm{Y} / \mathrm{L}]=\left(\frac{\beta}{1-\beta}\right) \operatorname{gr}[\mathrm{K} / \mathrm{Y}]
$$

Dimana $\beta$ adalah share modal terhadap total pendapatan dan dengan menggunakan nilai $\beta=1 / 3$ dalam perhitungan dan dengan mengganti $\mathrm{K}$ dengan W45, maka diperoleh persamaan sebagai berikut (Mason et al, 2017):

$$
\left.\operatorname{gr}[\mathrm{Y}(\mathrm{t}) / \mathrm{L}(\mathrm{t})]=0,5 \operatorname{gr}\left[\frac{\mathrm{WT} 45(\mathrm{t})}{\mathrm{Y}(\mathrm{t})}\right)\right]
$$

Selanjutnya hubungan pertumbuhan support ratio atau $\operatorname{gr}[\mathrm{SR}(\mathrm{t})]$ dan pertumbuhan rasio daur kesejahteraan pensiun terhadap total pendapatan tenaga kerja atau gr [W45(t)/Yl(t)] dinyatakan dalam persamaan berikut (Mason et al., 2017):

$$
\operatorname{gr}\left[\frac{\mathrm{Y}(\mathrm{t})}{\mathrm{N}(\mathrm{t})}\right]=\operatorname{gr}[\operatorname{SR}(\mathrm{t})]+0,5 \operatorname{gr}\left[\frac{\mathrm{W} 45(\mathrm{t})}{\mathrm{Yl}(\mathrm{t})}\right]
$$

Jika pertumbuhan support ratio dan rasio daur kesejahteraan pensiun terhadap total pendapatan tenaga kerja bernilai negatif, maka dampaknya merugikan pertumbuhan ekonomi. Demikian sebaiknya jika support ratio dan rasio daur kesejahteraan pensiun terhadap total pendapatan tenaga kerja makin meningkat dan bernilai positif, maka dampaknya terhadap pertumbuhan ekonomi semakin besar.

Bonus demografi pertama, kedua dan pertumbuhannya menurut wilayah ditampilkan pada tabel 2. Bonus demografi pertama dialami pertama kali oleh di Eropa kemudian disusul Asia, Oseania, Amerika dan terakhir Afrika. Puncak bonus demografi pertama dan kedua terjadi di Asia masingmasing dengan nilai support ratio tertinggi 1,38 dan rasio daur hidup kesejahteraan pensiun terhadap total pendapatan tenaga kerja sebesar 1,88. Bonus demografi pertama dan kedua di Asia masing-masing berlangsung selama 20 tahun dan 42 tahun. Puncak bonus demografi gabungan juga terjadi Asia dengan nilai sebesar 2,34 yang berlangsung selama 34. Di semua wilayah bonus demografi kedua berlangsung lebih lama dibandingkan bonus demografi pertama.

Tabel 2. Bonus Demografi Pertama, Kedua dan Pertumbuhannya Menurut Wilayah

\begin{tabular}{lccccccc}
\hline Wilayah & $\begin{array}{c}\text { Awal Bonus } \\
\text { Demografi } \\
\text { Pertama }\end{array}$ & \multicolumn{2}{c}{$\begin{array}{c}\text { Puncak Bonus Demografi } \\
\text { (durasi dalam tahun) }\end{array}$} & $\begin{array}{c}\text { Pertumbuhan Bonus Demografi } \\
\text { dalam 100 tahun (\%) }\end{array}$ \\
\cline { 3 - 8 } & & Pertama & Kedua & Gabungan & Pertama & Kedua & Gabungan \\
\hline Afrika & 1993 & $0,82(25)$ & $1,33(51)$ & $1,80(48)$ & 0,32 & 0,67 & 1,00 \\
Amerika & 1975 & $0,84(19)$ & $1,15(43)$ & $1,51(33)$ & 0,15 & 0,67 & 0,82 \\
Asia & 1973 & $1,38(20)$ & $1,88(42)$ & $2,35(34)$ & 0,18 & 0,72 & 0,90 \\
Eropa & 1962 & $0,68(22)$ & $1,24(37)$ & $1,35(28)$ & $-0,08$ & 0,56 & 0,48 \\
Oseania & 1974 & $0,66(14)$ & $1,24(38)$ & $1,50(28)$ & 0,09 & 0,71 & 0,80 \\
\hline
\end{tabular}

Sumber: Mason et al., (2017).

Wilayah dengan durasi bonus demografi pertama, kedua dan gabungan terpanjang adalah Afrika yakni dengan durasi masing-masing 25 tahun, 51 tahun dan 48 tahun. Dalam 100 tahun, pertumbuhan bonus demografi pertama tertinggi terjadi di Afrika dengan pertumbuhan sebesar 0,32 persen kemudian disusul Asia, Amerika, Oseania dan terendah terjadi di Eropa dengan pertumbuhan minus (-0,08 persen). Disisi lain pertumbuhan bonus demografi kedua tertinggi terjadi di Asia kemudian disusul Oseania, Afrika dan Amerika dan pertumbuhan bonus demografi gabungan tertinggi terjadi Afrika kemudian disusul Asia, Amerika, dan Oseania. Sedangkan pertumbuhan bonus demografi kedua terendah terjadi di Eropa, demikian pula dengan pertumbuhan bonus demografi gabungan terendah juga terjadi di Eropa. 
Bonus demografi pertama akan berakhir setelah mengalami puncak dan pasca bonus demografi pertama ditandai dengan menurunnya taraf kehidupan penduduk. Setiap negara di Eropa akan mengalami pasca bonus demografi pertama pada tahun 2020. Sejumlah negara di Asia meliputi China, Korea, Vietnam, Thailand dan Jepang telah dan akan memasuki pasca bonus demografi pertama. Di Amerika dimana dua negara Kanada dan Amerika Serikat telah mengalami pasca bonus demografi pertama, tetapi Brazil masih mengalami bonus demografi hingga tahun 2024 dan Meksiko hingga tahun 2041 (Mason et al., 2017). Disisi lain, dampak kumulatif bonus demografi pertama setelah 100 tahun ditampilkan pada tabel 3. Di Afrika tingkat kehidupan penduduk pasca bonus demografi pertama mengalami penurun dari 100 pada tahun 1 (pertama) menjadi 90,6 pada tahun ke-100 atau mengalami penurunan sebesar 9,4. Sementara di Amerika pasca bonus demografi pertama dimana tingkat kehidupan penduduk mengalami penurunan dari 100 pada tahun 1 (pertama) menjadi 85,9 pada tahun ke-100 atau mengalami penurunan sebesar 14,1. Di Asia, Eropa dan Oseania tingkat kehidupan penduduk pasca bonus demografi pertama masing-masing mengalami penurunan dari 100 pada tahun 1 (pertama) menjadi masing-masing sebesar 82,6 dan 81,0 kemudian 84,8 pada tahun ke-100. Dengan perkataan lain, tingkat kehidupan penduduk di Asia, Eropa dan Oseania pasca bonus demografi pertama mengalami penurunan masing-masing sebesar 17,4 dan 19,0 dan 15,2. Hal ini menggambarkan bahwa penurunan tingkat kehidupan penduduk pasca bonus demografi pertama tertinggi adalah di Eropa yakni sebesar 19,0 dan terendah di Afrika sebesar 9,4.

Tabel 3. Dampak Kumulatif Pasca Bonus Demografi Pertama Menurut Wilayah

\begin{tabular}{lccccc}
\hline \multirow{2}{*}{ Wilayah } & \multicolumn{5}{c}{ Pasca Bonus Demografi Pertama } \\
\cline { 2 - 6 } & $\mathbf{1}$ & $\mathbf{2 5}$ & $\mathbf{5 0}$ & $\mathbf{7 5}$ & $\mathbf{1 0 0}$ \\
\hline Afrika & 100 & 98,0 & 95,3 & 94,1 & 90,6 \\
Amerika & 100 & 95,1 & 89,6 & 86,8 & 85,9 \\
Asia & 100 & 92,7 & 85,9 & 89,6 & 82,6 \\
Eropa & 100 & 90,1 & 84,0 & 82,6 & 81,0 \\
Oseania & 100 & 95,7 & 91,6 & 87,4 & 84,8 \\
\hline
\end{tabular}

Sumber: Mason et al., (2017).

\section{SIMPULAN}

Perhitungan bonus demografi meliputi dua model, yakni rasio ketergantungan dan ekonomi daur hidup. Model rasio ketergantungan mencakup empat metode yaitu metode Cheung et al., Adioetomo, Komine \& Kabe, dan Golini. Sedangkan model ekonomi daur hidup mencakup dua metode yaitu rasio dukungan dan rasio daur hidup kesejahteraan pensiun terhadap total pendapatan tenaga kerja. Merujuk pada keempat metode dalam model rasio ketergantungan, tiga metode yang telah dikembangkan dalam perhitungan bonus demografi GDPK Kabupaten Lombok Timur 2020-2045 yakni metode Cheung et al, Adioetomo, dan Komine \& Kabe. Sedangkan metode Golini belum dikembangkan. Berdasarkan metode Cheung et al., Kabupaten Lombok Timur telah mengalami bonus demografi pada tahun 20352045 dan berdasarkan metode Adioetomo Kabupaten Lombok Timur dalam periode 2020-2045 belum mengalami bonus demografi dan berdasarkan metode Komine dan Kabe dimana Kabupaten Lombok Timur mengalami bonus demografi dalam periode 2020-2045. Metode Golini belum bisa dikembangkan karena BPS Lombok Timur belum melakukan perhitungan rasio ketergantungan berdasarkan definisi rasio ketergantungan yang dikemukakan Golini. Di sisi lain, model ekonomi daur hidup terdiri dari dua metode yaitu rasio dukungan (support ratio) untuk menghitung bonus demografi pertama dan rasio daur hidup kesejahteraan pensiun terhadap total pendapatan tenaga kerja untuk menghitung bonus demografi kedua belum bisa dikembangkan di Kabupaten Lombok Timur karena semua data yang diperlukan untuk perhitungan tersebut belum tersedia di BPS Lombok Timur. Kedepan, model rasio ketergantungan yang meliputi empat metode dan model ekonomi daur hidup meliputi dua metode hendaknya dikembangkan dalam perhitungan bonus demografi Revisi GDPK Kabupaten Lombok Timur 2020-2045, RPJMD Lombok Timur 2023-2028 dan RPJPD Lombok Timur 2025-2045. Revisi GDPK Kabupaten Lombok Timur 2020-2045 hendaknya dilakukan secara berkala setiap lima tahun. 


\section{DAFTAR PUSTAKA}

Adioetomo, S. M. (2012). Transisi Demografi, Bonus Demografi dan the Window of Opportunity. Jakarta: Universitas Indonesia.

Aliman Muhammad, Tuti Mutia, Dahri Hi Halek, Rafika Hasanah, Hujairah Hi Muhammad. (2020). Pengembangan Instrumen Tes Kemampuan Berpikir Spasial Bagi siswa SMA. Geodika:Jurnal Kajian Ilmu dan Pendidikan Geografi, 4 (2):1-10.

Bloom, D., Canning, D., \& Sevilla, J. (2003). The Demographic Dividend: A New Perspective on The Economic Consequences of Population Change. Rand Corporation.

BPS Lombok Timur. (2020). Proyeksi Penduduk Lombok Timur 2010-2045. Selong: Badan Pusat Statistik Lombok Timur.

BPS. (2012). Analisis Statistik Sosial: Bonus Demografi dan Pertumbuhan Ekonomi. Jakarta: Badan Pusat Statistik.

Cheung, S. L. K., Yip, P. S. F., Chi, I., Golini, A., \& Robine, J. M. (2004). Change in Demographic Window in Low Fertility Countries. Paper presented at the International Seminar on the Demographic Window and Health Aging: Socioeconomic Challenges and Opportunities, Beijing, 10-11 May 2004.

Golini, A. (2014). A Domestic and an International View from a Demographic Window. Paper presented at the International Seminar on the Demographic Window and Health Aging: Socioeconomic Challenges and Opportunities, Beijing 10-11 May 2014.

Heryanah, H. (2015). Ageing Population dan Bonus Demografi Kedua di Indonesia. Populasi, 23(2), 1 16.

Hirschman, C. (2011). The Demographic Transition in Asia: 1950 to2050. Malaysian Journal of Tropical Geography, 42(1\&2), 1-10.

Jalaludin \& Fahri, A. (2013). Analisis Parameter Sosio-Demografik Provinsi Nusa Tenggara Barat. Jurnal Ekonomi dan Bisnis, 23(2), 135-142.

Kabul, L. M. \& Haliliah. (2019). Bonus Demografi dan Metode Perhitungannya dalam Lalu Nuzulul Kuswan, Julio Darenoh, Lalu Muh. Kabul (ed.): Pengembangan Materi Pendidikan Kependudukan Sesuai Kearifan Lokal. Mataram: Perwakilan BKKBN Provinsi Nusa Tenggara Barat.

Kabul, L. M. (2019). Manajemen Pembangunan Kependudukan: Koreksi Terhadap Teori Malthus. Ganec Swara, 13(2), 317-325.

Komine, T., \& Kabe, S. (2009). Long-term forecast of the demographic transition in Japan and Asia. Asian Economic Policy Review, 4(1), 19-38.

Lee, R. (2003). The demographic transition: three centuries of fundamental change. Journal of economic perspectives, 17(4), 167-190.

Makripuddin, L. (2019). Optimisme Menghadapi Bonus Demografi dan Revolusi Industri 4.0. Mataram: Perwakilan BKKBN Provinsi Nusa Tenggara Barat.

Mason, A., Lee, R., Abrigo, M., \& Lee, S. H. (2017). Support ratios and demographic dividends: Estimates for the World. Technical Paper, (2017/1).

Neuman, W. L. (2014). Social Research Methods: Qualitative and Quantitative Approaches Seventh Edition. England: Pearson.

Oey-Gardiner, M. \& Gardiner, P. (2013). Indonesian's Demographic Dividend or Window of Opportunity. Masyarakat Indonesia, 39(2), 481-504.

Peraturan Presiden Nomor 153 Tahun 2016 tentang Grand Design Pembangunan Kependudukan

Undang Undang Nomor 23 Tahun 2014 tentang Pemerintahan Daerah.

United Nations. (2013). National Transfer Accounts Manual: Measuring and Analysing the Generational Economy. New York:Population Division Departement of Economic and Social Affairs, United Nations. 